Adıyaman Üniversitesi Sağlık Bilimleri Dergisi, 2020;6(2):167-173

doi:10.30569.adiyamansaglik.706404

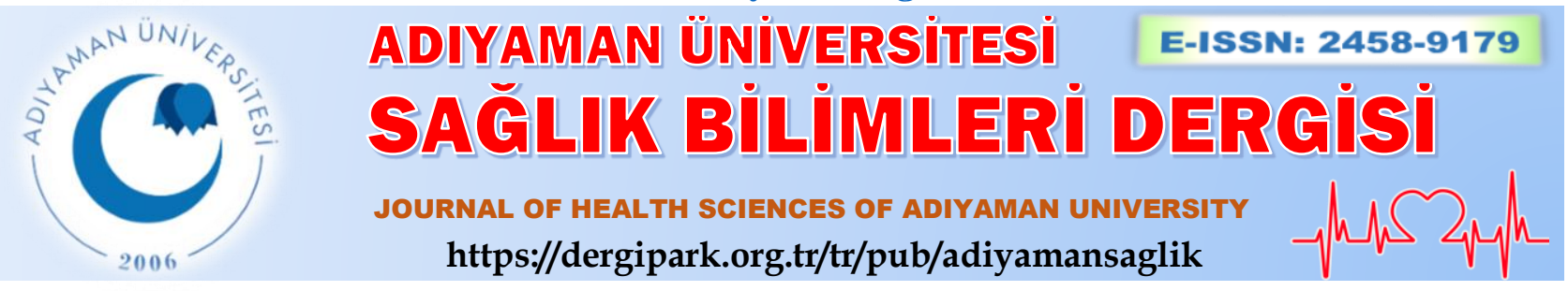

Özgün Araştırma/Research Article

\title{
Üniversite öğrencilerinin günlük besin ögesi alımlarının Akdeniz diyeti kalite indeksi (KIDMED) ile ilişkisi
}

\section{The relationship between intakes of daily nutrients and the Mediterranean diet quality index (KIDMED) in university students}

\author{
Aylin BAYINDIR GÜMÜŞ 1 @(D), Hülya YARDIMCI ${ }^{1}$ (ic \\ ${ }^{1}$ Ankara Üniversitesi, Sağlık Bilimleri Fakültesi, Beslenme ve Diyetetik Bölümü, 06290, Ankara-Türkiye
}

Atıf gösterme/Cite this article as: Bayındır Gümüş A, Yardımcı H. Üniversite öğrencilerinin günlük besin ögesi alımlarının Akdeniz diyeti kalite indeksi (KIDMED) ile ilişkisi. ADYÜ Sağllk Bilimleri Derg. 2020;6(2):167-173. doi:10.30569.adiyamansaglik.706404

Öz

Amaç: Üniversite öğrencilerinin günlük enerji, besin ögesi alımları ile Akdeniz diyetine uyumları arasındaki ilişkinin değerlendirilmesidir.

Gereç ve Yöntem: Çalışma 18-24 yaş arası 465 üniversite öğrencisi ile yürütülmüştür. Veriler soru formu kullanılarak toplanmıştır. Uygun istatistiksel analizler yapılmıştır.

Bulgular: Ortalama yaş $21,1 \pm 1,4$ yıldır. Ortalama KIDMED puanları 4,0 2,4 'dır ve $\% 8,6$ 's 1 en iyi diyet kalitesine sahiptir. Günlük alınan enerji ve makro besin ögeleri olan karbonhidrat, protein, yağ ve mikro besin ögeleri olan $\mathrm{B}_{1}, \mathrm{~B}_{2}, \mathrm{~B}_{3}, \mathrm{~B}_{6}, \mathrm{C}$ vitamini, folat, kalsiyum, demir, çinko, potasyum, magnezyum ve fosfor ile indeks puanı arasında pozitif yönde, istatistiksel açıdan anlamlı zayıf ilişkiler saptanmıştır $(p<0,05)$.

Sonuç: Günlük alınan enerji, makro ve mikro besin ögeleri ile KIDMED puanı arasında zayıf pozitif korelasyonlar bulunmuştur. Daha geniş örneklem ile çalışmalar yapılmalıdır.

Anahtar Kelimeler: Öğrenci; Besin Ögesi; KIDMED.

\begin{abstract}
Aim: The aim of this study was to evaluate the relationship between daily energy, nutrient intake and adaptation to the Mediterranean diet of university students.

Materials and Methods: The study was carried out with 465 university students aged 18-24. The data were collected using a questionnaire. Appropriate statistical analyzes have been made.

Results: The mean age of participants is $21.1 \pm 1.4$ years. The mean score of KIDMED was $4.0 \pm 2.4$ and $8.6 \%$ of them has the best diet quality. There were positive, statistically significant but weak relationships between daily energy, macro nutrient such as carbohydrate, protein, fat, and micro nutrients such as vitamin B1, B2, B3, B6, C, folate, calcium, iron, zinc, potassium, magnesium, phosphorus intakes and index score $(p<0.05)$.

Conclusion: Positive correlations were found between daily intakes of energy, macronutrients, micronutrients, and KIDMED score. Studies should be done with a larger sample.
\end{abstract}

Keywords: Student; Nutrient; KIDMED.

Yazışma Adresi/Address for Correspondence: Aylin BAYINDIR GÜMÜŞ, Ankara Üniversitesi, Sağllk Bilimleri Fakültesi, Beslenme ve Diyetetik Bölümü, Tepebaşı Mahallesi Fatih Caddesi No:197/A 06290, Ankara-Türkiye, E-mail: dytaylin@outlook.com

Geliş Tarihi/Received:19.03.2020 Kabul Tarihi/Accepted:05.05.2020

Yayım Tarihi/Published online:30.08.2020

Bu eser, Creative Commons Atıf-GayriTicari 4.0 Uluslararası Lisansı ile lisanslanmıștır. Telif Hakkı @ 2020 Adıyaman Üniversitesi Rektörlüğü 


\section{Giriş}

Yaşayan Akdeniz uygarlıkları yerleşik bir yaşam tarzına sahiplerdir. Geçmişten günümüze bulundukları bölgenin özellikleri itibari ile tarım yapabilmek için verimli topraklara sahip olmuşlardır. Bütün bunlar zeytin ve çeşitli sebze-meyve yetiştiriciliğinin yapılmasına ortam hazırlamıştır ve Akdeniz diyeti sağllk üzerinde gösterdiği olumlu etkileri nedeni ile 1960'lı yılların başında ilgi konusu olmuştur. ${ }^{1}$ Akdeniz diyeti, Akdeniz ülkelerinde özellikle kardiyovasküler hastalıkların diğer ülkelere kıyasla çok az sıklıkta görüldüğünün fark edilmesi ile dikkat çekmiştir. ${ }^{2}$ Akdeniz diyetinin, dünya genelinde sağlık için herkes tarafindan benimsenmesi gerektiği vurgulanmıştır. Son yıllarda Birleşmiş Milletler Eğitim, Bilim ve Kültür Örgütü ve Birleşmiş Milletler Gıda ve Tarım Örgütü Akdeniz diyetinin doğru beslenme şekli ve yaşam tarzı olduğu konusunda fikir birliğine varmışlardır. ${ }^{3,4}$ Akdeniz diyeti besinsel, ekonomik ve sosyokültürel boyutları ile sürdürülebilir bir beslenme modelidir. $\mathrm{Bu}$ tür beslenme tarzı biyoçeşitlilik açısından da önemli olup; günümüz ve gelecek nesillerin sağlıklı bir yaşam devam ettirebilmelerinde etkilidir. ${ }^{5}$ Akdeniz diyetinin sahip olduğu en önemli özellik besin çeşitliliğidir. ${ }^{6} \mathrm{Bu}$ diyet türünde meyve-sebze, kurubaklagil ve kompleks karbonhidratların tüketiminin daha sık, balık tüketiminin orta ve kırmızı et tüketiminin daha az siklıkta olması önerilmektedir., ${ }^{1,6,7}$ Diyet aynı zamanda temel yağ kaynağı olarak zeytinyağı kullanımını ve yemekler ile birlikte düşük-orta düzeyde kırmızı şarap tüketimini de içermektedir. ${ }^{6,7}$ Bununla birlikte Akdeniz diyetinin benimsenmesi ile, kardiyovasküler hastalıkların yanı sıra, bazı kanser türleri, Tip 2 diyabet ve bazı nörodejeneratif hastalıkların görülme sıklığı da azalabilmektedir. ${ }^{8}$

Akdeniz Diyet modeli beslenme temelinde sağlıklı ve dengeli diyet yağı örüntüsüne sahip olmanın yanı sıra, düşük glisemik indeks ve yüksek antioksidan ve posa alımı ile karakterizedir. Temelinde işlenmemiş bitkilerden elde edilen besinler, zeytinyağı ve deniz ürünlerinin tüketimi yer almaktadır. ${ }^{9}$ Özellikle vücut depo yağlarının belirli bir oranın üzerinde olması ile oluşabilecek obezite, kardiyovasküler hastalıklar, tip 2 diyabet ve bazı inflamatuar hastalıkların oluşum sıklığının Akdeniz diyet tarzını benimseyen bireylerde daha az görüldüğü bildirilmektedir. $\mathrm{Bu}$ diyetin koruyuculuğunun başta zeytinyağ 1 olmak üzere yüksek miktarda taze sebze meyve tüketimine bağlı olduğu düşünülmektedir. ${ }^{10}$ Ayrıca Akdeniz diyeti ile tekli ve çoklu doymamış yağ asitlerinin alımındaki artış, kanda hem trigliserit ve LDL-kolesterol düzeyini arttırmakta hem de HDL-kolesterol düzeyini azaltmaktadır. $\mathrm{Bu}$ metabolik etki insülin direncini dolaylı olarak engellemektedir. Epidemiyolojik veriler ise yüksek miktarda sebze meyve, tam tahıl, balık ve ürünleri tüketiminin, bulaşıcı olmayan kronik hastalıkların önlenmesi için gerekli olduğunu desteklemektedir. ${ }^{11}$ Dolayısı ile bu beslenme tarzı günlük besin ve besin ögesi alımını optimal düzeye taşıyarak yaşam kalitesinin arttırılmasında etkin olmaktadır. ${ }^{12}$

Öte yandan üniversite öğrencilerinin, üniversite yıllarının bir bölümü adölesan dönem ile çakışmaktadır. $\mathrm{Bu}$ nedeni ile fiziksel açıdan gelişimleri devam etmekte, yaşam şekilleri ve beslenme alışkanlıkları değişmekte ve enerji, besin ögesi gereksinimleri etkilenmektedir. ${ }^{13} \mathrm{Bu}$ etki genellikle olumsuz yöndedir. Ülkemizde öğrenim gören üniversite öğrencileri ile yapılan çalışmalarda üniversite öğrencilerinde öğün atlama, fast food tüketimi, yanlış besin seçiminin yaygın ve sağlıklı beslenme ile ilgili bilgi düzeylerinin yetersiz olduğu bildirilmektedir. ${ }^{14-17}$ Öğrencilerin beslenme alışkanlıkları birçok faktörden etkilenmekte, sağlıksız beslenme alışkanlıkları ileri yaşlarda görülebilecek birçok kronik hastalık açısından risk oluşturmaktadır. ${ }^{18}$ Buna bağlı olarak üniversite öğrencilerinin diyet kalitesinin, günlük alınan enerji ve besin ögesi alımları ile ilişkili olabileceği düşünülmektedir. $\mathrm{Bu}$ çalışmada üniversite öğrencilerinin diyet kalite düzeyleri ile günlük enerji, besin ögesi ve posa alımları arasındaki ilişkinin değerlendirilmesi amaçlanmıştır.

\section{Gereç ve Yöntem}

Araştırmanın tipi 
Çalışmamızın türü uygulamalı, tanımlayıcı, kesitsel, örnekleme ve epidemiyolojik araştırma niteliğindedir.

Çalışmadaki bağımlı değişken (diğer değişkenlerden etkilendiği düşünülen) KIDMED puanı, dolayısı ile diyet kalite düzeyidir. $\mathrm{Bu}$ değişken üzerine etkisi olduğunu düşündüğümüz değişkenler ise sosyodemografik özellikler, BKİ, günlük enerji ve makro, mikro besin ögesi alım miktarlarıdır. Çalışmanın hipotezini Akdeniz diyet modeline uyum düzeyi ile günlük besin alım düzeyi arasındaki olası ilişkisi oluşturmuştur.

\section{Araştırmanın evreni ve örneklemi}

$\mathrm{Bu}$ çalışma Ankara ilinde yaşayan, 18-24 yaş arasında olan, gönüllü ve sağlıklı iletişim kurabilen üniversite öğrencileri ile yürütülmüştür. Eylül 2018-Mart 2019 tarih aralığını kapsayan araştırma süresince (altı ay) en fazla gönüllü sayısına ulaşılmaya çalışılmış, 465 öğrencinin verileri değerlendirilmiştir.

\section{Veri toplama araçları}

Veriler araştırmacılar tarafindan hazırlanan ve uygulanan soru formu ile toplanmıştır. Soru formu katılimciların sosyodemografik özellikleri, 24 saatlik hatırlatma yöntemi ile besin tüketim kaydı ve Akdeniz Diyeti Kalite İndeksini (KIDMED) içermiş, veri toplama süresi her birey için yaklaşık 15 dakika sürmüştür.

Öğrencilerin Akdeniz diyetine uyum düzeyinin belirlenmesi için KIDMED kullanılmıştır. $\mathrm{Bu}$ indeks, 16 adet sorudan oluşmakta; olumsuz çağrışımlı sorulara “-1", olumlu çağrışımlı sorulara " $+1 "$ puan verilmektedir. $\mathrm{Bu}$ indeksten alınan toplam puan üç düzeyde sınıflandırılmaktadır. $\mathrm{Bu}$ sinıflamaya göre; $\geq 8$ puan "optimal" diyet kalitesini, 4-7 puan "ortalama" diyet kalitesini (iyileştirme gereklidir), $\leq 3$ puan "çok düşük" (minimum) diyet kalitesini yansitmaktadır. ${ }^{19}$

\section{Verilerin analizi}

Veriler SPSS (Statistical Package for the Social Sciences) 15.0 istatistik programı ile Windows ortamında değerlendirilmiştir. Besin tüketim kayıtlarından elde edilen sonuçlar ise Beslenme Bilgi Sistemi (BeBİSBLS II.3, 1999) kullanılarak önce Excel daha sonra SPSS programına aktarılarak analiz edilmiştir.

Tanımlayıcı istatistikler ortalama, standart sapma ( $\bar{X} \pm \mathrm{SS})$, alt-üst değerler, frekans dağılımı ve yüzde olarak gösterilmiştir. İkili grupların ortalamalarının karşılaştırılmasında, verilerin normal dağılım gösterdiği Kolmogorov-Smirnov testi ile doğrulandığından "Independent $\mathrm{t}$ testi" ve ikiden fazla grupların karşılaştırılmasında "OneWay ANOVA testi" kullanılmıștır. Katogerik verilerin değerlendirilmesinde, Chi-square $\left(X^{2}\right)$ testinden yararlanılmıştır. Yaş, beden kütle indeksi (BKİ), günlük enerji (kkal), besin ögesi alımları ile KIDMED puanı arasındaki ilişkinin belirlenmesinde, Pearson korelasyon testi uygulanmıştır. Korelasyon katsayısı değerlendirilmesi; 0.000.10 (ihmal edilebilir), 0.10-0.39 (zayif), 0.40-0.69 (orta düzey), 0.70-0.89 (güçlü) ve $0.90-1.00$ (çok güçlü) şeklinde yapılmıştır. ${ }^{20}$ $p<0.05$ değeri istatistiksel olarak anlamlılık kabul edilmiştir.

\section{Bulgular}

Çalışmaya yaş ortalaması $21,1 \pm 1,4$ y1 olan, çoğunluğu yurtta kalan $(\% 63,4), 3$. ve 4 . sinifa devam eden (sirasi ile; \%30,5 ve $\% 31,8) 401 \mathrm{k1z}(\% 86,2)$ ve 64 erkek $(\% 13,8)$ üniversite öğrencisi katılmıştır (Tablo 1).

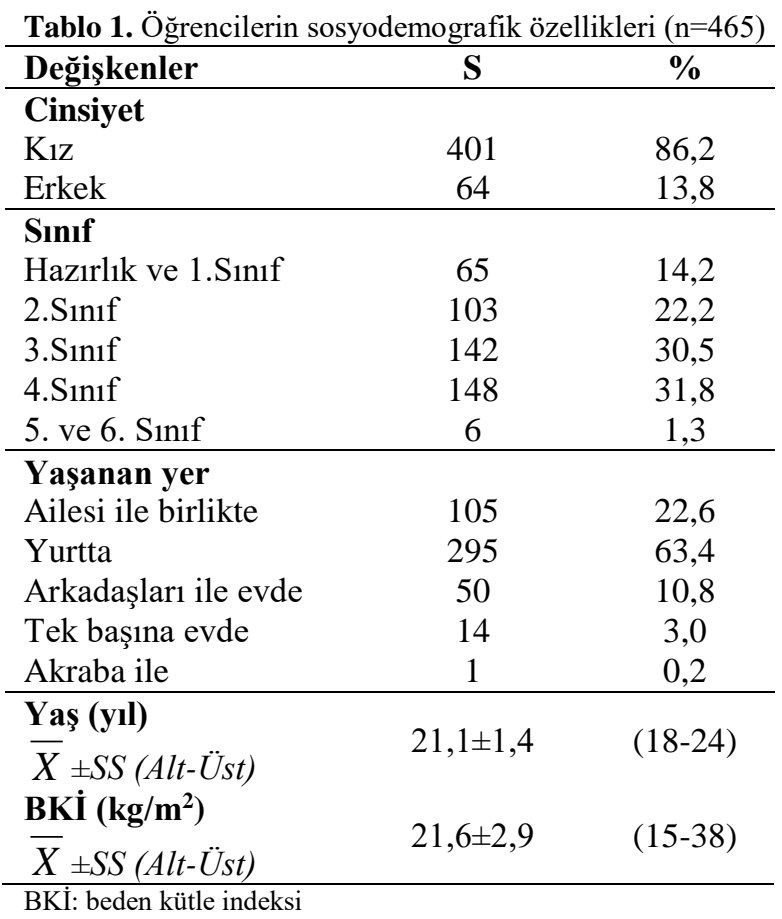


Tablo 2'de öğrencilerin cinsiyete göre diyet kalitesi (KIDMED) dağılımları verilmiştir. Çalışmaya katılan üniversite öğrencilerinin yaklaşık yarısının $(\% 48,8)$ ortalama diyet kalitesinde olduğu tespit edilmiştir. Cinsiyete göre diyet kalitesi düzeylerinin dağılımları ve ortalama KIDMED puanları arasında istatistiksel farklılık bulunmamıştır $(p>0,05)$.

Tablo 2. Öğrencilerin cinsiyete göre diyet kalitesi (KIDMED) $(\mathrm{n}=465)$

\begin{tabular}{|c|c|c|c|c|c|c|c|}
\hline \multirow{2}{*}{$\begin{array}{l}\text { Diyet } \\
\text { kalitesi }\end{array}$} & \multicolumn{2}{|c|}{ Kız } & \multicolumn{2}{|c|}{ Erkek } & \multirow[b]{2}{*}{$p$} & \multicolumn{2}{|c|}{ Toplam } \\
\hline & $\mathbf{S}$ & $\%$ & $\mathbf{S}$ & $\%$ & & $\mathbf{S}$ & $\%$ \\
\hline $\begin{array}{l}\text { En iyi } \\
\text { diyet } \\
\text { kalitesi* }\end{array}$ & 36 & 9,0 & 4 & 6,3 & & 40 & 8,6 \\
\hline $\begin{array}{l}\text { Ortalama } \\
\text { diyet } \\
\text { kalitesi* }\end{array}$ & 200 & 49,9 & 27 & 42,2 & $>0.05$ & 227 & 48,8 \\
\hline $\begin{array}{l}\text { Çok } \\
\text { düşük } \\
\text { diyet } \\
\text { kalitesi* }\end{array}$ & 165 & 41,1 & 33 & 51,5 & & 198 & 42,6 \\
\hline $\begin{array}{l}\bar{X} \\
\pm S S^{* *} \\
\left(A l t-\ddot{U}_{s t}\right)\end{array}$ & \multicolumn{2}{|c|}{$\begin{array}{c}4,0 \pm 2,3 \\
(-2)-(11)\end{array}$} & \multicolumn{2}{|c|}{$\begin{array}{c}3,4 \pm 2,6 \\
(-2)-(10)\end{array}$} & $>0.05$ & \multicolumn{2}{|c|}{$\begin{array}{c}4,0 \pm 2,4 \\
(-2)-(11)\end{array}$} \\
\hline
\end{tabular}

Katılımcıların yaş-indeks puanı ve BKİindeks puanı arasında istatistiksel açıdan anlamlı bir ilişki yoktur $(p>0,05)$. Sınıf ve yaşanan yer gruplamasına göre indeks puanı anlamlı olarak değişmemiştir $(p>0,05)$ (Tablo 3).

Tablo 3. Öğrencilerin sınıf, yaşadıkları yere göre KIDMED puanlarının yaş ve BKİ ile ilişkisi

\begin{tabular}{|c|c|c|c|}
\hline \multirow{2}{*}{ Değişkenler } & \multicolumn{3}{|c|}{ KIDMED Puanı } \\
\hline & \multicolumn{2}{|c|}{$\mathbf{r}$} & $p$ \\
\hline Yaş (yıl)* & \multicolumn{2}{|c|}{0,067} & $>0,05$ \\
\hline \multirow[t]{2}{*}{ BKİ $\left(\mathrm{kg} / \mathrm{m}^{2}\right)^{*}$} & \multicolumn{2}{|c|}{0,025} & $>0,05$ \\
\hline & $\overline{\bar{X}} \pm \mathbf{S S}$ & (Alt-Üst) & $p$ \\
\hline \multicolumn{4}{|l|}{ Sinıf** } \\
\hline Hazırlık ve 1. Sinıf & $4,1 \pm 2,1$ & $(-1)-(8)$ & \multirow{5}{*}{$>0,05$} \\
\hline 2.Sinif & $3,8 \pm 2,3$ & $(-2)-(10)$ & \\
\hline 3.Sinif & $3,7 \pm 2,2$ & $(-2)-(10)$ & \\
\hline 4.Sinif & $4,3 \pm 2,7$ & $(-2)-(11)$ & \\
\hline 5. ve 6. Sinif & $5,3 \pm 1,4$ & $(3)-(7)$ & \\
\hline \multicolumn{4}{|l|}{ Yaşanan yer** } \\
\hline Ailesi ile birlikte & $4,4 \pm 2,3$ & $(-2)-(10)$ & \multirow{4}{*}{$>0,05$} \\
\hline Yurtta & $3,8 \pm 2,3$ & $(-2)-(11)$ & \\
\hline $\begin{array}{l}\text { Arkadaşları ile } \\
\text { evde }\end{array}$ & $3,7 \pm 3,0$ & $(-2)-(11)$ & \\
\hline Tek başına evde & $4,6 \pm 2,8$ & $(0)-(8)$ & \\
\hline
\end{tabular}

Öğrencilerin günlük alınan enerji (kkal), makro besin ögeleri $(\mathrm{g} / \mathrm{mg} / \mathrm{mcg})$, posa $(\mathrm{g})$, kolesterol alımları (mg) ile KIDMED puanı arasındaki ilișki Tablo 4'te olduğu gibidir.

Tablo 4. Öğrencilerin günlük alınan enerji, makro besin ögeleri, posa, kolesterol alımları ile KIDMED puanı arasındaki ilişki

\begin{tabular}{lcc}
\hline Enerji ve besin & \multicolumn{2}{c}{ KIDMED Puanı } \\
\cline { 2 - 3 } ögeleri* & $\mathbf{r}$ & $\mathbf{p}$ \\
\hline Enerji (kkal) & 0,162 & $<0,05^{*}$ \\
Karbonhidrat (g) & 0,096 & $<0,05^{*}$ \\
Karbonhidrat (\%) & $-0,080$ & $>0,05$ \\
Protein (g) & 0,161 & $<0,05^{*}$ \\
Protein (\%) & 0,044 & $>0,05$ \\
Yağ (g) & 0,166 & $<0,05^{*}$ \\
Yağ (\%) & 0,060 & $>0,05$ \\
Posa (g) & 0,141 & $<0,05^{*}$ \\
Suda çözünür posa (g) & 0,119 & $<0,05^{*}$ \\
Suda çözünmez posa & 0,164 & $<0,05^{*}$ \\
(g) & 0,200 & $<0,05^{*}$ \\
DYA (g) & 0,182 & $<0,05^{*}$ \\
TDYA (g) & 0,047 & $>0,05$ \\
ÇDYA (g) & 0,015 & $>0,05$ \\
$\omega-3$ (mg) & 0,051 & $>0,05$ \\
$\omega-6$ (mg) & 0,132 & $<0,05^{*}$ \\
Kolesterol (mg) & & \\
ÇDYA: çoklu doymamış yağ asiti; DYA: doymuş yağ & asiti, TDYA: \\
tekli doymamış yağ asiti & & \\
p $<0.05$, *Pearson korelasyon testi uygulanmıştır. &
\end{tabular}

Günlük alınan enerji, karbonhidrat, protein ve yağ miktarı, posa (suda çözünür ve suda çözünmez), doymuş yağ asiti, tekli doymamış yağ asiti ve kolesterol ile KIDMED puanı arasında anlamlı korelasyonlar bulunmuştur (zayıf ve pozitif yönde) $(p<0,05)$ (Tablo 4$)$.

Günlük alınan potasyum, kalsiyum, magnezyum, fosfor, demir, çinko, $\mathrm{B}_{1}, \mathrm{~B}_{2}, \mathrm{~B}_{3}$, $\mathrm{B}_{6}$ vitaminleri, folat ve $\mathrm{C}$ vitamini ile KIDMED puanı arasinda anlamlı korelasyonlar bulunmuştur (zayıf ve pozitif yönde) $(p<0,05)$ (Tablo 5).

\section{Tartışma}

Beslenme sağlıklı bir yaşam sürdürmenin temelidir. Bu anlamda Akdeniz tipi beslenme oldukça önemli ve olumlu sağlik etkilerine sahiptir. Bu çalışma 18-24 yaş arasındaki 465 üniversite öğrencisi ile yürütülmüştür. Akdeniz Diyeti Kalite İndeksi puanı değerlendirildiğinde, erkek öğrencilerin yarıdan fazlasının $(\% 51,5)$ çok düşük, kız öğrencilerin ise \%49,9'unun ortalama diyet kalitesine sahip olduğu saptanmıştır. Yapılan bir çalışmada, ${ }^{21}$ erkek öğrencilerin 
\%63,3'ünün, k1z öğrencilerin \%48,5'inin çok düşük diyet kalitesine sahip olduğu bildirilmiștir.

Tablo 5. Öğrencilerin günlük alınan mikro besin ögeleri ile KIDMED puanı arasındaki ilişki

\begin{tabular}{|c|c|c|}
\hline \multirow{2}{*}{$\begin{array}{l}\text { Enerji ve besin } \\
\text { ögeleri* }\end{array}$} & \multicolumn{2}{|c|}{ KIDMED Puanı } \\
\hline & $\mathbf{r}$ & $p$ \\
\hline Sodyum (mg) & 0,080 & $>0,05$ \\
\hline Potasyum (mg) & 0,222 & $<0,05^{*}$ \\
\hline Kalsiyum (mg) & 0,300 & $<0,05^{*}$ \\
\hline Magnezyum (mg) & 0,226 & $<0,05^{*}$ \\
\hline Fosfor (mg) & 0,266 & $<0,05^{*}$ \\
\hline Demir (mg) & 0,148 & $<0,05^{*}$ \\
\hline Çinko (mg) & 0,182 & $<0,05^{*}$ \\
\hline A vitamini (mcg) & 0,031 & $>0,05$ \\
\hline E vitamini (mg) & 0,068 & $>0,05$ \\
\hline $\mathrm{B}_{1}$ vitamini (mg) & 0,220 & $<0,05^{*}$ \\
\hline $\mathrm{B}_{2}$ vitamini (mg) & 0,207 & $<0,05^{*}$ \\
\hline $\mathrm{B}_{3}$ vitamini (mg) & 0,108 & $<0,05^{*}$ \\
\hline $\mathrm{B}_{6}$ vitamini (mg) & 0,165 & $<0,05^{*}$ \\
\hline Folat (mcg) & 0,194 & $<0,05^{*}$ \\
\hline C vitamini (mg) & 0,133 & $<0,05^{*}$ \\
\hline $\mathrm{B}_{12}$ vitamini (mcg) & 0,049 & $>0,05$ \\
\hline
\end{tabular}

T1p Fakültesi birinci sınıf öğrencileri ile yapılan benzer bir çalışmada ise; öğrencilerin $\% \% 48,7$ 'sinin ç̧ok düşük, \%47,7'sinin ortalama diyet kalitesine sahip oldukları belirlenmiştir. Ancak bu çalışmada erkeklerde çok düşük diyet kalitesi, kızlarda ise ortalama diyet kalitesine sahip olanlar fazla olmasının nedeni; kızların beslenmelerine çeşitli nedenler ile daha fazla özen göstermeleri özellikle beden imajları algılarının daha yüksek olması ile açıklanabilir. Aynı çalışmada yurtta kalanların, ailesinin yanında kalanlara kiyasla 3,08 kat, ailesinden ayr1 evde kalanlarda ailesinin yanında kalanlara kıyasla 5,05 kat diyet kalitesinin daha kötü olduğu saptanmıştır. ${ }^{22} \mathrm{Bu}$ çalışmada ise yaşanılan yere göre diyet kalitesi düzeyi değişmemiş $(p>0,05)$; cinsiyet, yaş ve BKİ'ye göre diyet kaliteleri anlamlı olarak farklılaşmamıştır $(p>0,05)$. Yapılan bazı çalışmalarda, katılımcıların sosyodemografik özellikleri ile diyet kalite puanları arasında istatistiksel olarak anlamlı sonuçlar saptanmıştır. Kıbrıs'ta özel ve devlet üniversitesine devam eden öğrenciler ile yürütülen çalışmada ise, Akdeniz diyeti uyum düzeyinin dağılımı cinsiyete göre farklılık göstermiştir $(p<0,05) .{ }^{23}$ Yapılan başka bir çalışmada da, fazla kilolu çocuklarda BKİ ile KIDMED puanı arasında negatif ilişki bulunmuştur. $^{24}$ Çocuk ve adölesanların KIDMED puanlamasında; $\leq 3$ puan alanların 4-7 puan alanlara kıyasla ortalama BKI değerlerinin daha yüksek olduğu saptanmıştır. ${ }^{25}$ Serra-Majem ve arkadaşları (2004) ${ }^{19}$ düşük diyet kalitesi oranının düşük sosyoekonomik gruplarda daha yüksek olduğunu, yaş ve cinsiyete göre anlamlı farklılıklar olmadığını ifade etmişlerdir. $\mathrm{Bu}$ çalışmada ise ebeveyn eğitim durumu, gelir durumu gibi özellikler sorgulanmamıș olup; bu özellikler için istatistiksel olarak bir farklılık olup olmadığı konusuna yorum getirilememiştir.

Akdeniz ülkelerinde enerjinin büyük kısmı protein ve yağlardan karşılanmakta, karbonhidratların ise daha az olduğu bilinmektedir. ${ }^{26}$ Genç İspanyol bireyler ile yapılan bir araştırmada, KIDMED puanı ile değerlendirilen diyet kalitesi, diyet enerji yoğunluğu ile negatif ilişkili bulunmuştur. Dolayısı ile diyette enerji yoğunluğu yüksek (hamur işleri gibi) besin tüketimi arttıkça KIDMED puanı düşmekte; sebze-meyveler gibi enerji yoğunluğu düşük besinlerin tüketimi arttıkça KIDMED puanı artmaktadır. ${ }^{27}$ Ancak Peng ve arkadaşlarının çalışmasında (2019), ${ }^{28}$ Akdeniz diyetine uyum düzeyi arttıkça günlük enerji ve diyet posası tüketiminin arttığı belirtilmiştir. Benzer şekilde vitaminlerden $\mathrm{A}, \mathrm{E}, \mathrm{C}, \mathrm{B}_{1}, \mathrm{~B}_{2}, \mathrm{~B}_{3}, \mathrm{~B}_{6}$, $\mathrm{B}_{12}$ ve folat alımları; minerallerden kalsiyum, demir, magnezyum, fosfor, potasyum, sodyum, çinko ve bakır ile de aynı ilişki bulunmuştur. Makro besin ögelerinden sadece kızlarda enerjinin proteinden gelen oranı ile böyle bir durum söz konusudur. Bu çalışmada ise günlük enerji (kkal), karbonhidrat $(\mathrm{g})$, protein $(\mathrm{g})$, yağ $(\mathrm{g})$, diyet posas $1(\mathrm{~g}), \mathrm{C}, \mathrm{B}_{1}$, $\mathrm{B}_{2}, \mathrm{~B}_{3}, \mathrm{~B}_{6}$, folat vitaminleri ve potasyum, kalsiyum, magnezyum, fosfor, demir ve çinko ile KIDMED puanı arasında pozitif ilişski saptanmıștır.

Üniversite öğrencilerinde Akdeniz diyetine uyum ve günlük besin ögesi alımı arasındaki ilişkiyi araştıran herhangi bir çalışmaya rastlanmasa da literatürde bazı kronik hastalık gruplarında bu durum merak konusu olmuştur. Castro-Quezada ve arkadaşlarının 
(2014) derleme makalesinde, kanser ve kardiyovasküler hastalıklar gibi kronik hastalığa sahip hem çocuk hem de yetişkin bireylerin diyetlerinin Akdeniz diyetine özgü besinleri içermesi ve bu diyet tarzına bağlı1ığın artması, mikro besin alım yetersizliklerinin azalması ile sonuçlanmıştır. $^{29}$ Akdeniz diyet tarzının genellikle hastalıkların iyileştirilmesi yönündeki katkıları araştırılırken, sağlıklı ve özellikle üniversite öğrencileri gibi yanlış besin tercihinin yüksek olduğu gruplardaki durumun tespit edilmesi oldukça önemlidir.

\section{Araştırmanın kısıtlılıkları}

$\mathrm{Bu}$ çalışmada araştırma süresini artırmamak için, ebeveyn eğitim durumu, gelir durumu gibi özellikler gibi bazı genel özellikler sorgulanmamıştır. Ayrıca çalıșma süresinin kısıtlı ve kesitsel olması nedeni ile 24 saatlik geriye dönük besin tüketim kaydı kullanılmıştır. Katılımcıların beslenme alışkanlıklarını daha iyi yansıtması amacı ile ileride yapılacak çalışmalarda üç veya yedi günlük besin tüketim kaydı sorgulanması yerinde olacaktır. Ayrıca çalışmanın esas amacını oluşturmadığından, çalışmaya katılan üniversite öğrencilerinin enerji ve besin ögesi alımlarının diyetle önerilen alım düzeyine (DRI) veya önerilen günlük besin alım miktarına (RDA) göre değerlendirilmesi yapılmamıştır. Dolayısıyla alım düzeylerine göre KIDMED puanı da değerlendirilmemiştir. Konu ile ilgili yapılacak çalışmalarda, bu parametrelerinde değerlendirilmesi yerinde olacaktır.

\section{Sonuç}

Sonuç olarak, bu çalışmada literatürde yapılan diğer çalışma sonuçlarına benzer olarak katılımcıların diyet kalite düzeylerinin düşük olduğu görülmüştür. Diyet kalitesinin arttırılması gerekmektedir ve özellikle bu yaş grubu bireylerde doğru besin tercihini sağlamak için programlar geliştirilmelidir. $\mathrm{Bu}$ programlar özellikle okul öncesi dönem çocuklarından başlayarak yeterli ve dengeli beslenmenin nasıl olacağı konusunda çeşitli paydaşlar ile (Sağlık Bakanlığı, Millî Eğitim Bakanlığı gibi) iş birliği yapılarak gerçekleştirilebilir. Üniversite yıllarında ise fakülte ya da bölüm ayırdı olmadan tüm üniversitelerde zorunlu beslenme dersi olarak gerçekleştirilebilir. Böylece daha sağlıklı nesiller ve toplumlar oluşturulabilir. Bilindiğgi üzere Akdeniz diyeti yüksek posa içeren, enerji yoğunluğu düşük ve mikro besin ögeleri açısından zengin besin tüketimini önermektedir. Çalışmada bu bilgileri destekleyen sonuçlar yer almaktadır. Ancak besin tüketim kaydının daha uzun süreli alındığı, besin bazlı soruların yer aldığ öğün tüketimlerinin de sorgulandığı, beslenme alışkanlıklarını içeren, daha geniş örneklem ile çalışmalar yapılması gerektiği düşünülmektedir.

\section{Araștırmanın Etik Boyutu}

$\mathrm{Bu}$ çalışmanın etik kurul onayı ilgili üniversitenin rektörlüğü Etik Kurulu Başkanlığ 16.07.2018 tarih ve 161 sayılı karar ile alınmıştır. Araştırma Helsinki Bildirgesi ilkelerine uygun olarak yürütülmüştür.

\section{Bilgilendirilmiş Onam}

Çalışmaya katılan tüm gönüllü bireyler bilgilendirilmiş onam formunu imzalamışlardır.

\section{Yazar Katkıları}

ABG ve HY bu çalışmanın fikir ve tasarımını oluşturmuşlardır. Verilerin toplanmas1 ve istatistiksel analizlerin yapılmas1 ABG'ye aittir. Bütün yazarlar istatistiksel analizleri değerlendirmiş, makalenin yazım aşamasına katkı sağlamış, makalenin sonuçlarını yorumlamış ve gözden geçirmiştir. Makalenin son hali tüm yazarlar tarafından onaylanmıştır.

\section{Çıkar Çatışması Beyanı}

Yazarların herhangi bir çıkara dayalı ilişkisi yoktur.

\section{Araştırma Desteği}

Çalışmayı maddi olarak destekleyen kişi/kuruluş yoktur.

\section{Beyanlar}

$\mathrm{Bu}$ çalışma, 22-24 Kasım 2019 tarihinde Gaziantep/Türkiye'de düzenlenen "3rd International Zeugma Conference on Scientific Researches" kongresinde sözel bildiri olarak sunulmuştur. 


\section{Kaynaklar}

1. Pérez-López FR, Chedraui P, Haya J, Cuadros JL. Effects of the Mediterranean diet on longevity and age-related morbid conditions. Maturitas. 2009;64(2):67-79.

2. Serra-Majem L, Roman B, Estruch R. Scientific evidence of interventions using the Mediterranean diet: a systematic review. Nutr Rev. 2006;64(suppl_1):S27-S47.

3. Burlingame B, Dernini S. Sustainable diets and biodiversity: directions and solutions for policy, research and action. http://www.fao.org/3/a-i3004e.pdf. Published November 2010. Accessed March 1, 2020.

4. Moro E. The Mediterranean diet from Ancel Keys to the UNESCO cultural heritage. A pattern of sustainable development between myth and reality. Procedia Soc Behav Sci. 2016;223:655-661.

5. Burlingame B, Dernini S. Sustainable diets: the Mediterranean diet as an example. Public Health Nutr. 2011;14(12A):22852287.

6. Barbaros B, Kabaran S. Akdeniz diyeti ve sağlı̆̆ koruyucu etkileri. Beslenme ve Diyet Dergisi. 2014;42(2):140-147.

7. Bach-Faig A, Berry EM, Lairon D, et al. Mediterranean diet pyramid today. Science and cultural updates. Public Health Nutr. 2011;14(12A):2274-2284.

8. Sofi F, Macchi C, Abbate R, Gensini GF, Casini A. Mediterranean diet and health status: an updated meta-analysis and a proposal for a literature-based adherence score. Public Health Nutr. 2014;17(12):2769-2782.

9. Bayram SŞ, Aktaş N. Akdeniz Diyeti ve Akdeniz Diyet Kalitesinin ölçümünde sıklıkla kullanılan indeksler. İçinde: Karaman MR, Artık N, Şanlıer N, editörler. International Eurasian Congress on "Natural Nutrition and Healthy Life' 1215 Temmuz 2018. Ankara: Ankara University Institute of Food Safety "Pelin Ofset\&Press; 2018: 572-578.

10. T.C. Sağlık Bakanlığı Yayın No: 1031. Türkiye beslenme rehberi TÜBER https://dosyasb.saglik.gov.tr/Eklenti/10915,tuber-turkiyebeslenme-rehberipdf.pdf. 2016'da basild1. 30 Nisan 2020'de erişildi.

11. Willett WC. The Mediterranean diet: science and practice. Public Health Nutr. 2006;9(1a):105-110.

12. Sofi F, Cesari F, Abbate R, Gensini GF, Casini A. Adherence to Mediterranean diet and health status: meta-analysis. BMJ. 2008;337:1-7.

13. Spear BA. Adolescent growth and development. J Am Diet Assoc. 2002;102:S23-S29.

14. Güleç M, Yabancı N, Göçgeldi E, Bakır B. Ankara'da iki kız öğrenci yurdunda kalan öğrencilerin beslenme alışkanlıkları. Gulhane Med J. 2008;50:102-109.

15. Orak S, Akgün S, Orhan H. Süleyman Demirel Üniversitesi öğrencilerinin beslenme alışkanlıklarının araştırılması. SDÜ Tip Fak Derg. 2006;13(2):5-11.

16. Ermiş E, Doğan E, Erilli N, Satıcı A. Üniversite öğrencilerinin beslenme alışkanlıklarının incelenmesi: Ondokuz Mayıs Üniversitesi örneği. Spor ve Performans Araştırmaları Dergisi. 2015;6(1):30-40.

17. Arslan SA, Daşkapan A, Çakır B. Üniversite öğrencilerinin beslenme ve fiziksel aktivite alışkanlıklarının belirlenmesi. TAF Prev Med Bull. 2016;15(3):171-180.

18. Mukudi E. Nutrition status, education participation, and school achievement among Kenyan middle-school children. Nutrition. 2003;19:612-616.

19. Serra-Majem L, Ribas L, Ngo J, et al. Food, youth and the Mediterranean diet in Spain. Development of KIDMED, Mediterranean Diet Quality Index in children and adolescents. Public Health Nutr. 2004;7(7):931-935.

20. Schober P, Boer C, Schwarte LA. Correlation coefficients: appropriate use and interpretation. Anesth Analg. 2018;126(5):1763-1768.

21. Vassigh G. Üniversite Öğrencilerinin Fiziksel Aktivite Durumları ile Sağlıklı Beslenme İndekslerinin Değerlendirilmesi [Yüksek lisans tezi]. Ankara, Türkiye: Hacettepe Üniversitesi/Sağlık Bilimleri Enstitüsü; 2012.

22. Akdemir M, Erengin H, Dönmez L. Tıp fakültesi birinci sınıf öğrencilerinin beslenme durumu ve ilişkili faktörler. International Peer-Reviewed Journal of Nutrition Research. 2016;8:34-49.
23. Hadjimbei E, Botsaris G, Gekas V, Panayiotou AG. Adherence to the Mediterranean diet and lifestyle characteristics of university students in Cyprus: a cross-sectional survey. J Nutr Metab. 2016. http://downloads.hindawi.com/journals/jnme/2016/2742841.pdf . 1 Mart 2020'de erişildi.

24. Kontogianni MD, Farmaki A-E, Vidra N, Sofrona S, Magkanari F, Yannakoulia M. Associations between lifestyle patterns and body mass index in a sample of Greek children and adolescents. J Acad Nut. Diet. 2010;110(2):215-221.

25. Kabaran S, Gezer C. Kuzey Kıbrıs Türk Cumhuriyeti’ndeki çocuk ve adolesanlarda Akdeniz diyetine uyum ile obezitenin belirlenmesi. Türkiye Çocuk Hastalıklarl Dergisi. 2013;7(1):11-20.

26. Moreno LA, Sarría A, Popkin BM. The nutrition transition in Spain: a European Mediterranean country. Eur J Clin Nutr. 2002;56(10):992-1003.

27. Schröder H, Mendez MA, Gomez SF, et al. Energy density, diet quality, and central body fat in a nationwide survey of young Spaniards. Nutrition. 2013;29(11-12):1350-1355.

28. Peng W, Berry E, Goldsmith R. Adherence to the Mediterranean diet was positively associated with micronutrient adequacy and negatively associated with dietary energy density among adolescents. J Hum Nutr Diet. 2019;32(1):41-52.

29. Castro-Quezada I, Román-Viñas B, Serra-Majem L. The Mediterranean diet and nutritional adequacy: a review. Nutrients. 2014;6(1):231-248. 